\title{
SEGURITIES REGULATION: SEVENTH GIRCUIT HOLDS THAT WITHDRAWABLE CAPITAL ACCOUNTS ARE NOT "SECURITIES" WITHIN THE MEANING OF THE EXCHANGE ACT
}

\begin{abstract}
Relying upon legislative history and the particular characteristics of the accounts, the Seventh Gircuit in Tcherepnin v. Knight held that withdrawable capital accounts in a savings and loan association are not "securities" within the ambit of the antifraud provisions of the Securities Exchange Act. This note explores the bases of the court's decision and suggests an alternative resolution which both furthers the purposes of the Act and preserves traditional state regulatory power in the savings and loan area.
\end{abstract}

F ollowing the financial decline of City Savings, an Illinois-chartered savings and loan association, the Tcherepnins, holders of withdrawable capital accounts in that association, ${ }^{1}$ brought an action seeking to rescind their purchases of shares and to be classified as creditors of the institution. ${ }^{2}$ The Tcherepnins alleged that their deposits had

\footnotetext{
1 Withdrawable capital accounts, as defined in the Illinois Savings and Loan Act, were ordinarily withdrawable in whole or in part at any time by the depositor. See ILL. REv. STAT. ch. 32, $\$ 773$ (a) (1965). The accounts were subject to forced retirement by the association. Id. $\S 775$. Furthermore, they were not negotiable and were nonassessable for debts or losses of the association, id. $\$ \$ 762$ (a), (c), 768 (c), although they were transferable, $i d$. $\$ 768(\mathrm{~b})$, and carried the right to receive dividends, $i d . \$ \$ 762(\mathrm{~b})$, 780 , and to vote on the association's affairs, id. $\$ 742$ (d) (2). See Brief for Appellants Knight \& Hulman at 7, Reply Brief for Apellants Knight \& Hulman at 3.7, Tcherepnin v. Knight, 371 F.2d 374 (7th Cir. 1967).

Painstaking effort has been expended in differentiating these accounts from the concept of corporate stock. See, e.g., Prather, Savings Accounts in Savings and Loan Associations, I5 BUS. LAwYER 44 (1959). One prominent author concludes that these should properly be characterized as general deposits, id. at 48 , and denominated "savings accounts," id. at 52. The principal distinction between the withdrawable capital account in a savings and loan association and the savings account in a bank is that the holder of the latter is uniformly considered to be a primary creditor of the bank, Comment, Bank Accounts: Transfer of Property at Death, 23 U. CHr. L. REv. 289, 304 n.I8 (1956); see Prather, supra at 48, whereas the holder of a savings and loan account is considered a secondary or subordinate creditor, see $i d$. at 50 . This would apparently bear on the priority of payment of claims, but not on the nature of the claim.

${ }^{2}$ Since 1958 City Savings had been operating on a limited withdrawal basis as a result of inability to meet its cash commitments. On July 9, 1959, the Illinois Savings and Loan Act was amended to allow associations so operating to accept new deposits, despite their condition, on an unlimited withdrawal basis. Illinois Savings and Loan Act of 1959, §4-13(h), [1959] 111. Laws 716 (repealed 1965). The present suit was brought shortly before the City Savings Association went into voluntary bankruptcy by vote of the shareholders on July 28,1964 , but when the embarrassed institution was already
} 
been made in reliance upon false and misleading solicitations mailed to them by the association in violation of section 10 (b) of the Securities Exchange Act of $1934 .{ }^{3}$ The plaintiffs invoked the jurisdiction of the district court under section 27 of the Act, ${ }^{4}$ seeking to recover their money plus interest as allowed by section 18 (a), ${ }^{5}$ thereby making it necessary for the court to determine whether withdrawable capital accounts were "securities" within the meaning of the Exchange Act. ${ }^{3}$ In overruling the defendants' motion to dismiss, the district court held that such accounts were "securities."

Upon interlocutory appeal, the Court of Appeals for the Seventh Circuit, in Tcherepnin v. Knight, ${ }^{8}$ reversed and remanded with instructions to dismiss the complaint for lack of federal jurisdiction. ${ }^{9}$ The court held that withdrawable capital accounts were not within the concept of a security for two reasons: (1) an examination of legislative history indicated that these accounts were intended by Congress to be exempt from the provisions of the Exchange Act; and (2) an examination of the nature of the accounts indicated that they do not possess the requisite characteristics of a "security."

The Securities Act of $1933,{ }^{10}$ followed by the Securities Exchange Act in $1934,{ }^{11}$ was designed to protect the investor in securities through the prohibition of market manipulation and through the requirement of disclosure adequate to enable a prospective investor to make an intelligent investment decision. ${ }^{12}$ To this end, the Securi-

in the custodial care of the Director of Financial Institutions of the State of Illinois. Tcherepnin v. Knight, 371 F.2d 374, 375 (7th Cir. 1967).

${ }^{8} 15$ U.S.C. $\$ 78 \mathrm{j}$ (b) (1964). The plaintiffs' argument seems to have been that the failure of City Savings to acknowledge in its solicitations that its financial situation was precarious and that it did not have federal deposit insurance for its accounts amounted to a deceptive practice within the prohibition of this section. See $371 \mathrm{~F} .2 \mathrm{~d}$ at $384-85$ (Cummings, J,, dissenting).

15 U.S.C. $\$ 78 \mathrm{aa}$ (1964) (allows federal jurisdiction even in the absence of diversity of citizenship).

Id. §78r (a) (1964).

- The SEC requested and was granted the opportunity to file an amicus brief, thus allowing its participation in this case of first impression. $371 \mathrm{~F} .2 \mathrm{~d}$ at 375; Brief for the SEC as Amicus Curiae at 1-2.

7371 F.2d at 375 .

831 F.2d 374 (7th Cir. 1967).

Id. at 379 .

1015 U.S.C. $\$ \S 77 \mathrm{a}-\mathrm{aa}$ (1964).

21 Id. $\$ \$ 78 \mathrm{a}-\mathrm{hh}(1964)$.

${ }_{12}$ H.R. REP. No. 85, $73 \mathrm{~d}$ Cong., 1st Sess. 2.3 (1933); see, e.g., Pasquesi, The Expanding "Securities" Concept, 49 ILI. B.J. 728 (1961); Comment, Banks and the Securities Act of 1933, 52 VA. L. REv. 117 (1966). 
ties Act, which is directed primarily at the distribution process, requires registration of securities and proscribes misleading representations. This Act, with unimportant exceptions, exempted from the registration requirements "any security issued by a . . . savings and loan association ...."13 There appears to have been substantial unanimity between the houses of Congress ${ }^{14}$ and representatives of the savings and loan industry ${ }^{15}$ that all savings and loan transactions would be exempt from registration. However, spokesmen for the industry indicated that they had no objection to the application of the antifraud provisions to their institutions, with the attendant requirement of disclosure to prospective investors. ${ }^{16}$

In contradistinction to the focusing of the Securities Act on the offering of an issue, the Securities Exchange Act of 1934 was concerned with trading after distribution. Its requirements extended to issuers of securities listed on an exchange. ${ }^{17}$ Since the registration provisions of the 1934 Act originally applied only to listed securities, ${ }^{18}$ any specific registration exemption for savings and loan associations, whose transactions are unlisted, would have been surplusage. Despite its different regulatory objective, the Exchange Act employed a definition of security almost identical to that of the Securities Act, with the exception of the omission of the term "evidence of indebtedness" from the 1934 Act definition. ${ }^{19}$

${ }^{18} 15$ U.S.C. $\$ 77 \mathrm{c}$ (a) (5) (1964). Political factors apparently motivated adoption of the exemption. Landis, The Legislative History of the Securities Act of 1933, 28 GEo. WASH. L. REv. 29, 39 (1959).

14 See H.R. REP. No. 152, 73d Cong., Ist Sess. 24 (1933) [hereinafter cited as 1933 REPORT].

${ }^{15}$ Hearings on S. 2408 Before a Subcomm. of the Senate Comm. on Banking and Currency, 81st Cong., 2d Sess. 181 (1950).

${ }^{10}$ Hearings on H.R. 4314 Before the House Comm. on Interstate and Foreign Commerce, 73d Cong., 1st Sess. 72-74 (1933). It should be noted that the structure of the Act is such that, once it is established that a "security" is involved, the antifraud provisions of the Act apply even though the security may have a registration exemption. 15 U.S.C. $\$ \$ 77 c(a), 1$ (2), g(c) (1964); see 1 L. Loss, SEcurities REculation 710 (2d ed. 1961); Pasquesi, supra note 12; Comment, 20 U. MIAMI L. REv. 919, 922 \& n.27 (1966).

${ }_{17}$ The Act's basic purposes were to require disclosure of certain information to the investor, to prevent fraud and manipulation in trading, and to regulate the amount of the nation's credit involved in the securities markets. See 15 U.S.C. §78b (1964); Peoples Sec. Co. v. SEC, 289 F.2d 268, 271 (5th Cir. 1961); 1 L. Loss, supra note 16, at 130-31.

${ }^{18}$ Securities Exchange Act of 1934 , ch. $404, \S 12,48$ Stat. 892, as amended, 15 U.S.C. $\S 781$ (1964).

10 The deletion of the term "evidence of indebtedness" from the 1934 Act definition is of questionable significance. The Tcherepnin court, in construing the Exchange Act definition, declined to analogize the instant case to cases which arose under the defini- 
In 1964 the Exchange Act was amended to afford investors in the larger unlisted companies the same protection accorded holders of listed securities, to expand the regulatory control over those in the securities industry, and to strengthen the standards for entrance into that business. ${ }^{20}$ In order to accomplish these purposes, the registration requirements were extended to issuers of over-the-counter securities who were engaged in interstate commerce or use of the mails and had total assets of over one million dollars and a class of equity securities held of record by at least 750 (subsequently 500) stockholders. ${ }^{21}$

The extension of registration requirements to over-the-counter issuers conceivably covered savings and loan associations whose shares may be traded in that manner. Further, the savings and loan registration exemption reappeared in a narrower form than its counterpart in the Securities Act:

The provisions of the subsection [referring to registration] shall not apply in respect of ... (c) any security, other than permanent stock, guaranty stock, permanent reserve stock, or any similar certificate evidencing nonwithdrawable capital, issued by a savings and loan association,... . which is supervised and examined by State or Federal authority having supervision over any such institution.22

The exemption thus removes certificates evidencing withdrawable capital accounts from the registration requirement. However, the 1934 Act's antifraud provisions, like those of the 1933 Act, apply to any "security," irrespective of exemption from registration. The question thus arises whether withdrawable capital accounts in a savings and loan association, such as City Savings, are to be considered

tion in the 1933 Act, viewing the omission as significant. 371 F.2d at 379 . See text accompanying notes 50 \& 51 infra. However, the dissenting judge pointed out that the significance is debatable, in that a question of draftsmanship and not of policy might have prompted the omission. See 371 F.2d at 880 n.3.

${ }^{20}$ S. REP. No. 379, 88th Cong., 1st Sess. 1.2 (1963); H.R. REP. No. 1418, 88th Cong., 2d Sess. 1-2 (1964); see Sowards, The Securities Acts Amendments of 1964: New Registration and Reporting Requirements, 19 U. MIAMI L. REv. 33, 39-85 (1964). See gen. erally Phillips \& Shipman, An Analysis of the Securities Acts Amendments of 1964, 1964 DuKe L.J. 706; Stiles, The Securities Acts Amendments of 1964, 6 CoRP. Prac. Comm. 344 (1965); 41 Denv. L.C.J. 374 (1964); 39 ST. John's L. REv. 111 (1964).

2115 U.S.C. $\$ 78 l(\mathrm{~g})(\mathrm{l})$ (1964); see Stiles, supra note 20, at 347.

${ }_{22} 15$ U.S.C. $\$ 78(\mathrm{~g})(2)(\mathrm{c})$ (1964) (emphasis added). The narrowing of the exemption has been decmed significant in its exclusion of capital stock. See Phillips \& Shipman, supra note 20 , at $743-44$. 
as "securities" and therefore subjected to the antitfraud provisions when distributed by issuers who meet the capital asset and stockholder tests, even though the 1964 amendments exempt these accounts from registration.

In considering this question, the majority opinion rejected the contention of the SEC that the exemption from registration of certain savings and loan securities in the 1964 amendments would have been unnecessary had such interests not been included in the original definition of "security." 23 The court analogized to insurance contracts, exempted under the $1933 \mathrm{Act}^{24}$ and noted that this exemption from registration did not mean that insurance contracts were otherwise classifiable as a security. Rather, the exemption of insurance contracts only indicated an excess of caution lest there be misunderstanding as to their proper categorization. ${ }^{25}$ With citations from congressional hearings on the 1964 amendments, the court extended its analogy to the substance of the transactions involved: as there is no stock or trading in stock involved in insurance contracts, so is there neither stock nor trading in stock involved in withdrawable capital accounts. ${ }^{26}$ Also, the presence of state regulation to counter abuses in the insurance field is parallelled by extensive state regulation over savings and loan associations, and such regulation is persuasive against the need for federal intervention. ${ }^{27}$ Summarily, the court posited that the purpose of the Exchange Act was the regulation of transactions involving actively traded securities in order to prevent price fluctations resulting from manipulation and speculation. ${ }^{28}$ The opinion indicates that those dangers were not viewed by the court to be attendant to these savings and loan transactions.

In sharp contrast to the majority's treatment of the legislative history, the dissenting judge attacked the analogy to exempted in-

${ }^{23}$ Brief for SEC as Amicus Curiae at 11-13. The Commission asserted that unless such accounts were held to be securities, the exemption could only be interpreted "in either of two inappropriate ways: that it is meaningless, hecause withdrawable shares would be excluded by definition, or that the term 'security' refers not to withdrawable shares but is confined solely to some other type of undefined and legislatively unconsidered security issued by a savings and loan association." Id. at 13.

2415 U.S.C. $\$ 78 l(\mathrm{~g})(2)(\mathrm{G})$ (1964).

${ }^{25} 371$ F.2d at 379 (citing H.R. REP. No. 85, 73d Cong., lst Sess. 15 (1933)).

26371 F.2d at 378 (citing Hearings on H.R. 6789, H.R. 6792, and S. 1642 Before the Subcomm. of the House Comm. on Interstate and Foreign Commerce, 88th Cong., 1st Sess. 309 (1963) [hereinafter cited as House Hearings]).

27371 F.2d at 378.

${ }^{28}$ See id. at $376,377$. 
surance contracts as invalid, since, in his view, such contracts did not possess the characteristics of securities and could not have been intended for inclusion in the definition. ${ }^{29}$ Further, to the dissenter, the language of the 1933 Act which exempted "any security issued by a ... savings and loan association ...."30 indicated that savings and loan accounts were regarded as securities, which were exempt from registration, but not from the antifraud provisions. ${ }^{31} \mathrm{He}$ argued that the 1964 amendments would not have exempted withdrawable accounts from registration had those accounts not been within the basic definition of a security. ${ }^{32}$

The legislative history of the Securities Act offers only questionable support for the majority's analogy between savings and loan transactions and insurance contracts. During the legislative deliberations, a committee report said of the insurance contract exemption:

\begin{abstract}
Paragraph (8) makes clear what is already implied in the act, namely, that insurance policies are not to be regarded as securities subject to the provisions of the act. The insurance policy and like contracts are not regarded in the commercial world as securities offered to the public for investment purposes. The entire tenor of the act would lead, even without this specific exemption, to the exclusion of insurance policies from the provisions of the act, but the specific exemption is included to make misinterpretation impossible.33
\end{abstract}

The weakness of the analogy between insurance contracts and savings and loan transactions lies in the fact that the House report did not direct a similar exclusionary discussion to savings and loan institutions, but merely stated that their "securities" were to be exempt from registration provided the institution confined itself to making loans to members. ${ }^{34}$

Examination of the hearings held on the 1964 amendments to the Exchange Act $^{35}$ provides little clarification of the ambiguous status of withdrawable capital accounts in savings and loan institutions. Apparently the study group responsible for investigating the proposed legislation was so concerned with the problems of other in-

${ }^{20}$ See id. at 380 (Cummings, J., dissenting).

${ }^{80} 15$ U.S.C. $\$ 77 \mathrm{c}(\mathrm{a})(5)$ (1964).

31 371 F.2d at $379-80$ (Cummings, J., dissenting).

${ }^{82}$ Id. at 380 .

${ }^{83}$ H.R. REP. No. 85, 73d Cong., 1st Sess. 15 (1933).

sid.

${ }^{a x}$ House Hearings, supra note 26. 
dustries that they did not investigate withdrawable capital accounts. Instead the group summarily asserted that the primary concern of federal securities regulation was the "permanent reserve" type accounts, actually representing stock in the enterprise. ${ }^{36}$

In summary, Congress has consistently expressed a desire to exempt savings and loan transactions from the registration requirements of the securities acts; but the question as to whether withdrawable accounts are securities within the ambit of the antifraud provisions is an open one. The court, however, concluded that, on balance, neither legislative history nor statutory construction indicated a congressional desire to subject these accounts to federal securities regulation.

As a second ground for decision, the court indicated that the peculiar characteristics of these accounts militated against their classification as a security. The controlling definition is given in section 3 (a) (10) of the Exchange Act:

The term "security" means any note, stock, treasury stock, bond, debenture, certificate of interest or participation in any profitsharing agreement or in any oil, gas, or other mineral royalty or lease, any collateral-trust certificate, preorganization certificate or subscription, transferable share, investment contract, voting-trust certificate, certificate of deposit, for a security, or in general, any instrument commonly known as a security; or any certificate of interest or participation in, temporary or interim certificate for, receipt for, or warrant or right to subscribe to or purchase, any of the foregoing; but shall not include currency or any note, draft, bill of exchange, or banker's acceptance which has a maturity at the time of issuance of not exceeding 9 months, exclusive of days of grace, or any renewal thereof the maturity of which is likewise limited.37

In practice, courts have been hesitant to give a strict construction to this definition lest such an approach serve as an invitation to sharp dealing by those desiring to avoid the provisions of federal regula-

80 "[N]ormally in many of these organizations [building and loan associations] the person who has an interest in the association [has] ... a savings interest. He doesn't have anything that he can usually transfer, as he can a share of stock, but in more recent years there has been a development in this area whereby stock in these organizations has been created for sale to the public as an investment. It is in this particular area that attention is being given to them within the purview of the securities acts." Id. at 273 (emphasis added).

${ }^{37} 15$ U.S.C. $\$ 78$ (c) (a) (10) (1964). 
tion. ${ }^{38}$ The judicial preference for ad hoc determinations is aided by the presence of the term "investment contract" within the definition. When a transfer fails to fit nicely into a specific category enumerated, the courts tend to apply the term "investment contract" in order to bring less standardized transactions within the coverage of the legislation. ${ }^{39}$ An investment contract as defined by the Supreme Court involves an "investment of money in a common enterprise with profits to come solely from the efforts of others." 40 In a long line of cases, the courts have been quick to find an investment contract where the buyer actually provided funds for another to use in a profit-making fashion, and where the proceeds were ratably distributed to those who bought into the venture. Furthermore, a finding of "investment contract" has frequently been made by courts confronted with investment schemes which have been couched not in terms of investment, but in terms of the purchase of commodities, coupled with separate contracts for the maintenance, service, or sale of the commodities by the seller or a third party, with the profits therefrom to be remitted to the buyer or customer. ${ }^{41}$

${ }^{38}$ SEC v. Crude Oil Corp. of America, 93 F.2d 844, 846-47 (7th Cir. 1937); see SEC v. W.J. Howey Co., 328 U.S. 293, 299 (1946). Although the courts seldom explicitly acknowledge this rationale as the basis for their broad interpretation of "security," the sentiment is inherent in their treatment of the cases, see note 41 infra, and especially evident in decisions involving Blue Sky laws, the background against which the federal securities laws were drawn, see, e.g., State v. Gopher Tire \& Rubber Co., 146 Minn. 52, 177 N.W. 937 (1920); State v. Whiteaker, 118 Ore. 656, 661, 247 P. 1077, 1079 (1926). The refusal of the judiciary to attempt a specification of the components of the security concept has been criticized as having an inhibiting effect on businessmen who hesitate to promote something which might later be determined to have been a "security" subject to the federal acts. Shipley, The SEC's Expanding Definition of a Security, 37 N.Y.S.B.J. 521 (1965).

${ }^{30}$ See cases cited note 42 infra. The SEC argued that the accounts in the instant case could be classified as stock, profit-sharing agreements, transferable shares, or investment contracts. Brief for SEC as Amicus Curiae at 14-15. Since the various categories of interests covered in the Securities Act definition were not meant to be mutually exclusive, 1 L. Loss, supra note 16, at 488-89, a given transaction may well fit one or more categories, see, e.g., SEC v. C.M. Joiner Leasing Corp., 320 U.S. 344, 351 (1943); SEC v. Wickham, 12 F. Supp. 245,249 (D. Minn. 1935). However, the "stock" and "transferable share" arguments would seem to be based primarily on the outmoded share terminology, rather than any substantive characteristics of the withdrawable capital accounts. See Prather, supra note 1 . See generally note 1 supra.

The suggestion that the accounts could be profit-sharing agreements would seem to be vitiated by the fact that no matter how much profit an association makes, the depositors receive only the amount remaining after certain distributions to mandatory and optional reserve accounts. ILL. REv. STAT. ch. 32, $\$ \$ 778$ (c), 779 (1965). Under some circumstances, no dividends at all may be paid. Id. $\$ 780$ (b) (1).

${ }^{\circ}$ SEC v. W.J. Howey Co., 328 U.S. 293, 301 (1946).

¿The courts have not been guided by the nature of the commodity behind the 
Linking these investment contract cases are three central themes: (1) there is commingling ${ }^{42}$ in the sense that the buyer's funds or chattels, or the proceeds from the venture, are pooled-the "common enterprise" characteristic; (2) there is separation of ownership and management with accompanying reliance by the buyer upon the abilities of the seller-the "efforts of others" characteristic; and (3) there is an element of speculation-the "profit"43 characteristic. The last requirement is illustrated in SEC $v$. Variable Annuity Life Insurance Company of America,4 ${ }^{44}$ where variable annuities were held not entitled to the exemption afforded insurance contracts, on the

instrument. SEC v. C.M. Joiner Leasing Corp., 320 U.S. 344, 352 (1943); see SEC v. Variable Annuity Life ins. Co. of America, 359 U.S. 65 (1959) (variable annuities); SEC v. W.J. Howey Co., 328 U.S. 293 (1946) (units in a citrus grove); Roe v. United States, 287 F.2d 485 (5th Cir.), cert. denied, 368 U.S. 824 (1961) (mineral lease); Blackwell v. Bentsen, 203 F.2d 690 (5th Cir.), cert. dismissed, 347 U.S. 925 (1953) (units in a citrus grove); Penfield Co. v. SEC, 143 F.2d 746 (9th Cir.), aff'd, 330 U.S. 585 (1944) (whiskey warehouse receipts); Atherton v. United States, 128 F.2d 463 (9th Cir. 1942) (oil leases); SEC v. Universal Serv. Ass'n, 106 F.2d 232 (7th Cir. 1939), cert. denied, 308 U.S. 622 (1940) (application blanks for contributions to "Plenocracy"); SEC v. Crude Oil Corp. of America, 93 F.2d 844 (7th Cir. 1937) (oil royalties); SEC v. American Int'l Sav. \&e Loan Ass'n, 199 F. Supp. 341 (D. Md. 1961) (capital stock); SEC v. Los Angeles Trust Deed \& Mtge. Exch., 186 F. Supp. 830 (S.D. Cal.), modified on other grounds, 285 F.2d 162 (9th Cir. 1960), cert. denied, 366 U.S. 919 (1961) (discounted trust deed notes); SEC v. Bourbon Sales Corp., 47 F. Supp. 70 (W.D. Ky. 1942) (whiskey warehouse receipts); SEC v. Bailey, 41 F. Supp. 647 (S.D. Fla. 1941) (tung trees); United States v. Davis, 40 F. Supp. 246 (N.D. Ill. 194I) (membership in cooperative association); SEC v. Payne, 35 F. Supp. 873 (S.D.N.Y. 1940) (silver foxes); SEC v. Pyne, 33 F. Supp. 988 (D. Mass. 194I) (fishing vessels); SEC v. Timetrust, Inc., 28 F. Supp. 34 (N.D. Cal. 1939), appeal dismissed, 118 F.2d 718 (9th Gir. 1941) (stock); SEC v. Wickham, 12 F. Supp. 245 (D. Minn. 1935) (contract for market speculation); Riegel v. Haberstro, 151 Pa. Super. 539, 30 A.2d 645 (1943) (contribntions to "Plenocracy"). See also Notes, 28 CALIF. L. Rev. 410 (1940); 46 Colum. L. Rev. 885 (1946); 37 Colum. L. Rev. 650 (1937); 36 ColuM. L. REv. 683 (1936); 53 MICH. L. REv. 140 (1954).

12 The commingling requirement is somewhat undercut by the holding in SEC v. Payne, 35 F. Supp. 873 (S.D.N.Y. 1940), where foxes were earmarked and identified to particular purchasers. However, various factors in that case tended to supply the requirement. For example, the form of contract used by the seller previously had provided for a pooling of offspring and profits. Also, the seller guaranteed a certain minimum number of offspring per year (3) and would make up deficiencies out of his own stock. Thus there was some possibility that the buyer might not receive in all cases the offspring of his breeding foxes. Furthermore, the court emphasized that no purchaser had ever asked for actual delivery. Id. at 878 .

${ }^{48}$ But see Silver Hills Country Club v. Sobieski, 55 Cal. 2d 811, 361 P.2d 906, 13 Cal. Reptr. 186 (1961); Miller, Cooperative Apartments: Real Estate or Securities?, 45 BostoN U.L. REv. 465 (1965); 50 CAIIF. L. REv. 156 (1962). The thrust of the Silver Hills decision was to replace the profit requirement with a requirement that there be an element of risk attached to any capital investment. For a discussion of various concepts of "profit," including an analysis of the Silver Hills case, see Coffey, The Economic Realities of a "Security": Is there a More Meaningful Formula?, 18 WEST. RES. L. REV. $367,398-403$ (1967).

«359 U.S. 65, 7 I (1959). 
theory that the issuer is not required to give a fixed return, but only - to remit a prorata amount based upon gains and losses from the investment portfolios in which these contracts participate. Conceivably, it is the characteristic of a variable return which leads courts to find a "security" because of the possibility of fraud and loss to the investor in situations where no definite return is guaranteed. Hence, on the basis of investment contract cases concerning everything from tung trees to whiskey warehouse receipts, the acts can hardly be said, despite the majority opinion in the instant case, to apply only to those situations in which there is active trading in the "securities."

Despite the broad range of transactions included under the above definitional approach, the court in Tcherepnin took a narrow categorical approach to the security definition, summarily dismissing the applicability of the "investment contract" term..$^{45}$ The court asserted that withdrawable capital accounts fit no category in the section 3 (a) (10) definition save perhaps an "instrument commonly known as a "security," "46 and that this possibility was vitiated by the action of the Illinois legislature in indicating, while statutorily creating such accounts, that they were not intended to be securities. ${ }^{47}$ Furthermore, examining the characteristics of the accounts, the court noted that they may be issued in unlimited amounts; they are not covered by the securities article of the Uniform Commercial Code; they are transferable only by assignment and are not negotiable; they are subject to forced redemption by the depositor and to retirement at the demand of the board of directors; they are fully matured and withdrawable at the time of issuance; they do not include preemptive rights; they are evidenced by an account book; and they do not entitle their holders to inspect the association's books and records, although the holders may vote for directors, give proxies, and receive dividends. The court posited that these characteristics render the

45 "An 'investor" in a savings and loan association lends his money to be withdrawable at will and to earn interest. The relationship with the enterprise is much more that of debtor-creditor than investment. The profit is derived from loans to other members of the savings and loan association. This is not investment in a common enterprise with profits to come solely from the efforts of others." 371 F.2d at 377.

40 Id. at 376.

"Id. Apparently, the court reasoned from the Illinois Savings and Loan Act, ILL. REv. STAT. ch. 32, $\$ 768$ (c) (1965), which indicates that withdrawable capital certificates and account books are not to be subject to Article 8, concerning investment securities, of the Uniform Commercial Code. 
accounts in question "unlike the ordinary concept of a security." 48

Finally, the majority held that the accounts represented a debtorcreditor relationship..$^{49}$ The court apparently attached much weight to indications in the legislative history of the 1934 Act that the term "evidence of indebtedness," present in the definition of security in the 1933 Act, was excluded from the 1934 definition in connection with consideration of accounts of building and loan associations. ${ }^{50}$ Hence, the court concluded that the debtor-creditor relationship evidenced by withdrawable capital accounts was not meant to fall within the ambit of the Exchange Act. ${ }^{51}$

The determination of the majority that these accounts are not classifiable as securities would seem open to attack on the investment contract theory, though possibly supportable by the debtor-creditor analysis. The extensive argument made by the SEC that withdrawable capital accounts satisfy the requirements of an investment contract is persuasive: there is commingling of the depositors' funds in a pool from which loans are to be made; there is complete separation of ownership and management; and there is an element of speculative gain, for since the return on money deposited is a portion of the profit made by the institution on loans, the dividend rate will follow fluctuations in the money market.

To the extent that the court failed adequately to distinguish, or seriously to counter, the investment contract argument, its reasoning is questionable. However, considering the debtor-creditor approach, the court would seem to be on somewhat firmer ground in rejecting the "security" concept. Unlike a stockholder who may lose the entirety of his investment if the enterprise fares badly, the savings account holder stands to lose nothing as his funds are fully withdrawable at any time. Viewed as a deposit, ${ }^{52}$ the withdrawable capital account is analogous to an ordinary bank savings account, plainly not a security. ${ }^{53}$ Also, as deposits, these accounts would seem to partake of the nature of short term debt transactions specifically ex-

4871 F.2d at 376 . See note 1 supra for a more complete discussion of the characteristics of these accounts.

10371 F.2d at $377-79$.

so See generally Reinoehl, Basic Pattern and Coverage of the 1933 Act, 34 U.M.K.C.L. REv. 172 (1966). But see note 19 supra.

${ }^{61}$ See 371 F.2d at 378 (citing Hearings on S. 875 Before the Senate Comm. on Banking and Currency, 73d Cong., 1st Sess. 94-120 (1933)).

52 Prather, supra note 1, at 47-69.

sa 15 U.S.C. $\$ 78 \mathrm{c}($ a) (12). But see Brief for SEC as Amicus Curiae at 26. 
empted from the definition of security. ${ }^{54}$ However, with regard to the debtor-creditor argument, a telling point was scored by the dissenter, who pointed out that these depositors, unlike creditors, were not entitled to interest, but only to a distribution of the profits of the association in the form of dividends. ${ }^{55}$

The weaknesses in the majority opinion, sharply pointed out by the dissent, are readily apparent, and surely did not escape the notice of the court. This leads to the conclusion that policy considerations, rather than substantive definitions, influenced the holding that these accounts were not subject to the registration or antifraud provisions of the federal securities acts. The lack of controlling congressional intent, coupled with the uncertain applicability of the security definition to withdrawable capital accounts, left the court free to implement the policy it found most desirable. Obviously that policy decreed the immunization of withdrawable capital accounts from federal securities regulation. Possibly this immunization was desired by the court because the savings and loan industry is presently a highly regulated one, and thus the need for additional regulation under the Exchange Act is unclear.

In addition to stringent regulation under state law, state-chartered savings and loan institutions frequently elect to seek coverage under two federal programs-the Federal Home Loan Bank System ${ }^{66}$ and the Federal Savings and Loan Insurance Corporation (FSLIC). ${ }^{57}$ Savings and loan associations, savings banks, and insurance companies which join the System must be examined at least once a year by representatives of the Federal Home Loan Bank Board. ${ }^{58}$ The assets and liabilities of the institution are verified, and a detailed audit of its accounts is made. Insurance from FSLIG is compulsory for federally-chartered

86 "The term 'security" ... shall not include ... any note ... which has a maturity at the time of issuance of not exceeding nine months . . .." Securities Exchange Act of 1934,15 U.S.C. $\$ 78 \mathrm{c}$ (a) (10) (1964). As the Tcherepnin court notes, 371 F.2d at 377 , these accounts are mature at issue. The dissenting judge, however, emphasizes that these accounts do not represent short term commercial paper, and therefore do not fall within this excluded category. Id, at $\mathbf{3 8 3}$.

A further argument against the idea that these accounts represent investment capital is found in the Illinois Savings arnd Loan Act. Whereas supervisors and examiners of savings and loans are forbidden to hold certain types of accounts, they may hold withdrawable capital accounts. InL. REv. STAT. ch. $32, \S 841.3$ (1965).

s5 371 F.2d at 383 (Cummings, J., dissenting).

${ }^{50}$ Federal Home Loan Bank Act $\S \S 1-30,12$ U.S.C. $\$ \S 1421-60$ (1964).

${ }^{67}$ National Housing Act $\$ \S 401-07,12$ U.S.C. $\$ \S 1724-30$ (1964).

${ }^{8}$ Federal Home Loan Bank Act $\$ 20,12$ U.S.C. $\$ 1440$ (1964). 
associations and may be obtained by state institutions. ${ }^{59}$ Coverage is granted only after ascertainment that the insured state-chartered associations follow fiscal policies approved by federal examiners.

It might seem that the pitfalls for the investor against which the federal securities acts were designed to guard are rare in the savings and loan industry. However, the background of the present case lessens the credibility of such a general statement, for City Savings, in trouble financially, was allowed to continue accepting deposits without advising depositors of their unstable situation. Conceivably, such a situation would not have arisen had City Savings been required to proceed in accordance with the disclosure mandates of the antifraud sections of the securities acts. It is precisely the possibility of loss to the investor which, as noted earlier, ${ }^{60}$ has impelled some courts toward a finding of "security" in a given transaction. ${ }^{61}$ The risk of loss from insured withdrawable accounts in savings and loan associations, of course, seems negligible. Yet, where insurance does not protect the accounts, losses can occur as the instant case indicates. Perhaps, then, it would not have been an unreasonable extension of the coverage of the 1934 Act for the court to have held that withdrawable capital accounts in an uninsured institution are securities amenable to the antifraud provisions, while such accounts in an insured institution are outside the definition of security. This analysis could be based on the concept that an uninsured institution is effec-

${ }^{60}$ As of 1961, the great majority of savings and loan associations belonging to the Federal Home Loan Bank System participated in the FSLIC insurance prograin. THE FEDERAL HOME LOAN BANE System 26 (1961). At present, the insurance covers up to $\$ 15,000$ per account. National Housing Act $\$ 405$ (a), 12 U.S.C. $\$ 1728$ (a) (Supp. $1966)$.

${ }^{\circ}$ See text preceding note 45 supra.

61 One writer has attempted to structure a scheme of analysis to determine the presence of a "security." Coffey, supra note 43. In answer to the question he poses himself, "What characteristics or features of a transaction necessitate its being subject to the rather specialized antifraud protection afforded by the securities laws?", id. at 373 , the writer posits "that risk to initial investment, though not determinative, is the single most important economic characteristic which distinguishes a security from the universe of other transactions." Id. at 375. Further, he casts a critical eye at the propensity of courts to emphasize the element of possible profit, or speculative gain, rather than properly emphasizing the risk of loss of the initial investment, see $i d$., as properly delineated in the Joiner decision and reiterated in Silver Hills, id. at 381-82. Determining the presence of a security through an examination of the risk-of-loss element would accord well with the conclusion reached by this note-that the presence or absence of account insurance should be determinative on the issue of security. See text accompanying note 62 infra. 
tively receiving investments which will have no more protection than that normally accorded risk capital.

Classification of uninsured withdrawable accounts as securities would undoubtedly stimulate uninsured associations to procure deposit insurance as an alternative to complying with the federal securities acts. Indeed, the holding would probably provide incentive for the states to require that state-chartered savings and loan associations insure depositor accounts, ${ }^{62}$ since by establishing this requirement the states could remove these accounts from regulation under the federal securities scheme and retain them within the ambit of state regulation.

\footnotetext{
"s Because of the wide publicity given "insured savings," the ordinary investor probably takes for granted that his deposits in a savings institution are insured. While it would not seem unduly burdensome to require of a state that it provide insurance for accounts sufficient to justify this expectation, the history of the Idaho compulsory participation program raises doubts as to whether the federal program provides an appropriate insurance vehicle. The Idaho statute required FSLIC insurance for associations formed after a specified date, though established units could still elect nonparticipation. See IDAHO CODE ANN. \$30-1301A (Supp. 1965). Shortly after its adoption, this provision was successfully attacked (1) as making an arbitrary distinction between new and old institutions, and (2) for unconstitutionally delegating legislative authority to a federal agency which could alter its regulations without prior state approval. See Idaho Sav. \& Loan Ass'n v. Roden, 82 Idaho 128, 350 P.2d 225 (1960). Irrespective of the validity of these arguments, they do serve to reflect the deslre of some tribunals to attempt a local solution to investor problems. In instances where this viewpoint prevails, implementation of a state funded and managed program would be acceptable, though the existence of individualized structures reflects limited administrative efficiency.
} 